\title{
Mikrofluidikai cella tervezése és gyártása spektroszkópiai ellipszométerhez
}

\section{Design and Manufacture of a Microfluidic Cell to Be Used With a Spectroscopic Ellipsometer}

\author{
Bíró Tamás, ${ }^{1}$ Renkó József Bálint ${ }^{2}$ \\ ${ }^{1}$ Budapesti Müszaki és Gazdaságtudományi Egyetem, Anyagtudomány és Technológia Tanszék \\ Budapest, Magyarország, biro.tamas@edu.bme.hu \\ ${ }^{2}$ Budapesti Müszaki és Gazdaságtudományi Egyetem, Anyagtudomány és Technológia Tanszék \\ Budapest, Magyarország, renko.jozsef@edu.bme.hu
}

\begin{abstract}
In material testing and manufacturing processes, creating thin layers is a widely used method for structure development or for surface treatment purposes. Despite its widespread use, the physical background of the layer development process is currently under-researched. Its examination requires the development of procedures and tools that, in combination with the existing tools, can help to understand these processes. The development of microfluidic cells is a way to solve this problem. In this paper, a newly developed microfluidic cell is presented, which also offers a solution to several problems encountered when using previous designs.
\end{abstract}

Keywords: microfluidic cell, design, manufacture, spectroscopic ellipsometry.

\section{Összefoglalás}

Anyagvizsgálatoknál vagy egyes gyártási eljárásokban igen gyakran alkalmazott módszer a vékonyrétegek létrehozása a szövetszerkezet előhívására, illetve felületkezelési célból. Az eljárás széles körü használata ellenére a rétegépülés folyamatának fizikai háttere jelenleg sem teljesen feltérképezett. Vizsgálatához olyan eljárások és eszközök kidolgozására van szükség, amelyekkel a meglévőket kombinálva a rétegépülés jelensége folyamatában nyomon követhetővé válik. Erre a problémára a mikrofluidikai cellák fejlesztése jelenthet megoldást. Jelen cikkben egy új fejlesztésű mikrofluidikai cellát mutatunk be, amely több, a korábbi cellák használata során jelentkező problémára is megoldást kínál.

Kulcsszavak: mikrofluidikai cella, tervezés, gyártás, spektroszkópiai ellipszometria.

\section{Bevezetés}

A metallográfiában széles körü felhasználásnak örvendenek a különböző maratási eljárások. Ezek egyik legelterjedtebb változata a színes maratás [1], ahol a marószer a polírozott minta felületével reakcióba lépve egy átlátszó filmréteget alakít ki. A fény a film felületéről visszaverődve interferál, ciklikus színváltozást okozva ezzel. A színváltozás sebességéből következtetni lehet a szemcsék orientációjára [2, 3]. A maratás folyamatában történő vizsgálatára ún. mikrofluidikai cellákat használnak, ahol a marószer egyenletes áramoltatása közben a minta felületén lejátszódó jelenségek optikai mikroszkóppal vagy spektroszkópiai ellipszométerrel is megfigyelhetők [3]. Ennek megvalósítását célzó koncepciók korábban is készültek, azonban megépítésükre gyártástechnológiai korlátok miatt nem kerülhetett sor [1]. Munkánk során egy olyan mikrofluidikai cella tervezését és gyártását tűztük ki célul, amellyel lehetőség nyílik a minta gyors cseréjén túl a nanométeres pontosságú spektroszkópiai ellipszo- 
metria [4] alkalmazására is, miközben optikai mikroszkóppal lehet a minta pozicionálását elvégezni, amelyre a korábbi koncepciók esetén nem volt lehetőség.

\section{Tervezés és gyártás}

A munka a követelmények meghatározásával kezdődött. Egyrészt adottak voltak a vizsgálandó beágyazott minta méretei, valamint a vizsgálatokra használt, Woollam M-2000DI típusú spektroszkópiai ellipszométer geometriai viszonyai. A tervezés során komoly kihívást jelentettek a berendezés méreteiből adódó korlátok. A készülék magassága nem haladhatta meg a $45 \mathrm{~mm}$-t, a fény útjának végig biztosítani kellett a $3 \mathrm{~mm}$ átmérőjü csatornát, ahol a közeghatárokon minden esetben a fény útjára merőleges felületeket kellett kialakítani. Végül törekedni kellett a lehető legkisebb belső üreg kialakítására, ugyanis azt a mérés előtt marószerrel fel kell tölteni. A hagyományos megmunkálást igénylő részek gyártása ugyanakkor bizonyos mérettartomány alatt nehézkessé válik.

\section{1. Általános felépítés}

A tervezett készülék felépítését az 1 . ábra mutatja. Szerkezetét tekintve három fő egységre, a polidimetil-sziloxán (PDMS) anyagú cellára, a hegesztett vázszerkezetre és a mintatartó tálcára bontható.

\subsection{A cella kialakítása}

A készülék legfontosabb része maga a cella, ahol a maratás folyamata és a vizsgálat zajlik (2. ábra). Ennek kémiailag inert, lehetőség szerint átlátszó, mérettartó anyagból kell készülnie, ezért a korábban már bevált, térhálós műanyagra, a PDMS-re esett a választás [1]. A cella formába öntéssel, majd térhálósítással készült, így a geometriának öntéshelyesnek kellett lenni, ami az alámetszett felületelemek mellőzését és megfelelő lekerekítések alkalmazását jelentette. A térhálósítás kemencében történik, így ez az alkalmazott öntőformák hőállóságát követelte meg $180{ }^{\circ} \mathrm{C}-\mathrm{ig}$. Az öntőformák kialakításuknak köszönhetően additív gyártással [5] vagy öttengelyes megmunkálóközpontban [6] is elkészülhetnek. Gazdasági megfontolások miatt az additív megmunkálással készített öntőformát választottuk.

A cella kialakításánál több szempontot is érvényesíteni kellett. A korábbi modell hátrányai közé tartozott, hogy a maratási folyamat kezdeti szakasza nem volt megfigyelhető, ugyanis a minta fölötti üreg feltöltése viszonylag sok ideig tartott [1]. Ennek térfogatát $851 \mathrm{~mm}^{3}$-ről $90 \mathrm{~mm}^{3}$-re

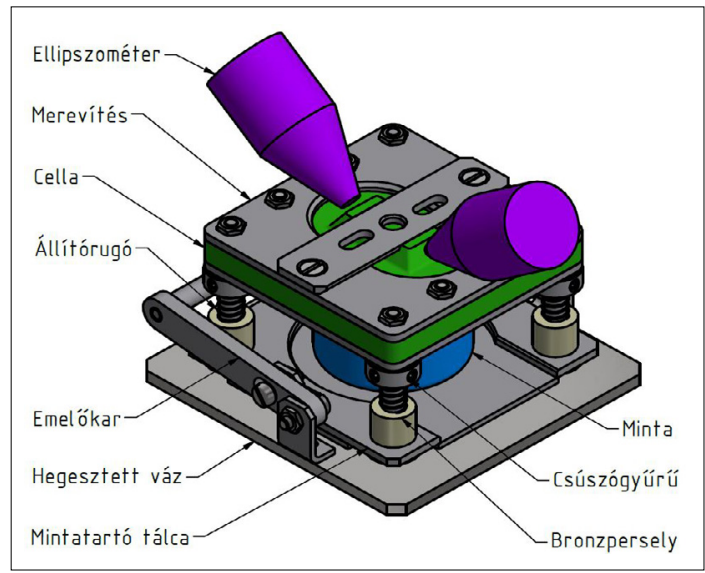

1. ábra. A tervezett készülék sematikus képe

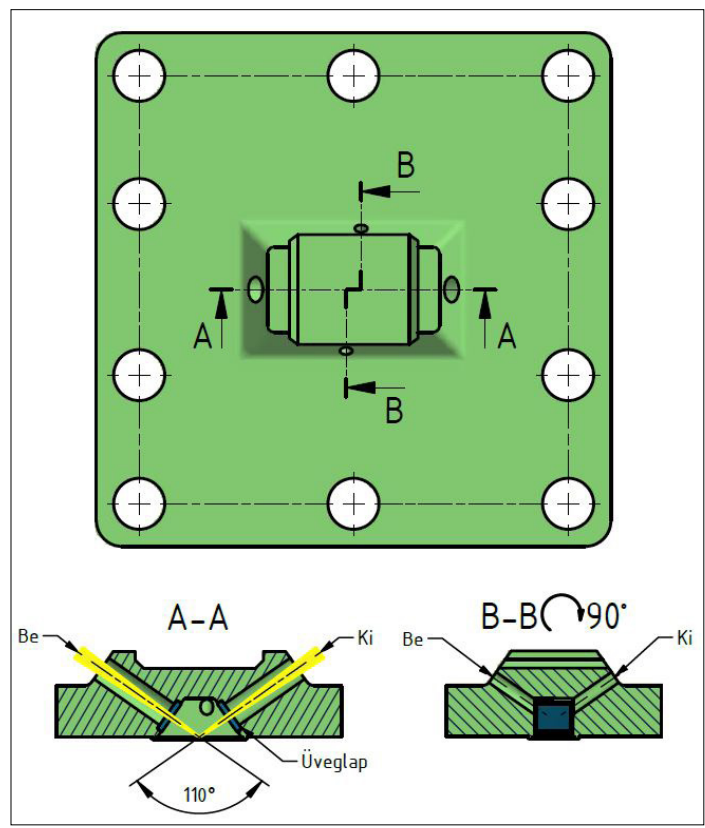

2. ábra. A cella felépítése; $A-A$ metszet: a fénynyaláb útja; $B$-B metszet: a marószer útja

csökkentettük, így az új cellánál azonos áramlási viszonyok mellett a feltöltés mindössze néhány másodpercet vesz igénybe. A vizsgálati fénynyaláb útjára merőleges felületek kialakításával a közeghatárokon fellépő fénytörés elkerülhető, illetve minimalizálható a gyártás pontosságától függően.

A spektroszkópiai ellipszometriában a minta felületéről visszavert fénynyaláb intenzitásmaximuma $55^{\circ}$-os beesési szög mellett érhető el [7, 8]. A fénynyaláb a cellába a 2. ábra A-A metszetén látható módon jut be. A belső üreg egy-egy ragasz- 
tott üveglappal van lezárva. A fény ezeken keresztül lép be, illetve hagyja el a kialakított üreget. A marószer be- és kivezetésére szolgáló csatornák erre merőlegesen, a 2. ábra B-B metszete által jelölt síkban lettek kialakítva. A két csatorna síkban eltolva helyezkedik el egymáshoz képest, ami megakadályozza a marószer pangását.

A minta felülete és a cella közötti tömítést egy, a cellában kialakított, 0,3 mm magasságú tömítőajak biztosítja. A rugónyomás hatására így a minta síkja az ellipszométer optikai tengelyeinek metszéspontjába kerül (3. ábra).

\subsection{Keretszerkezet}

A cella rugalmas deformációját, ezáltal a méréshez szükséges geometriai viszonyok megváltozását egy acél elemekből felépített, merev, hegesztett vázszerkezet akadályozza meg. Ennek az ellipszométer tárgyasztalán való pontos fekvését az alsó lapnak a hegesztés utáni síkba köszörülésével biztosítottuk, kompenzálva ezzel a hegesztés okozta deformációt.

A váz bronzperselyekkel biztosítja a mintatartó tálca cellával párhuzamos helyzetét, pontos futását. A minta cseréjét és pozicionálását a kialakított rugós mechanizmus segíti elő (4. ábra). A megfelelő tömítettség beállítása a rugóerő változtatásával lehetséges a mintatartó tálca alatt és fölött elhelyezkedő, egymással párhuzamosan kapcsolt rugópárok csúszógyűrüvel történő előfeszítésével.

A minta felületének pozicionálását a felső merevítésen kialakított betekintőfurat teszi lehetővé, akár optikai mikroszkóppal kombinálva is. A vizsgálat szempontjából releváns helyek a minta felületén megkereshetők, így az ellipszometria célzottan valósulhat meg a minta előkészített felületének bármely pontján.

További tervezési szempont volt, hogy a vázszerkezet a cella nélkül is önálló szerelési egységet alkosson, lehetővé téve így a fejlesztési folyamat részeként többféle cellakonstrukció behelyezését (5. ábra).

\section{Eredmények}

Munkánk eredményeként a mikrofluidikai cella prototípusa elkészült. A keretszerkezet összeszerelése után a készülék beállítása következett, ami a minta és a cella tömítettségét biztosító rugók megfelelő előfeszítését jelentette. A konstrukció mechanikailag kielégíti a tervezés során felmerülő igényeket, így a mintatartó tálca mozgatása, a minta cseréje és pozicionálása a készülék elmozdulása nélkül, könnyedén elvégezhető. A továb-

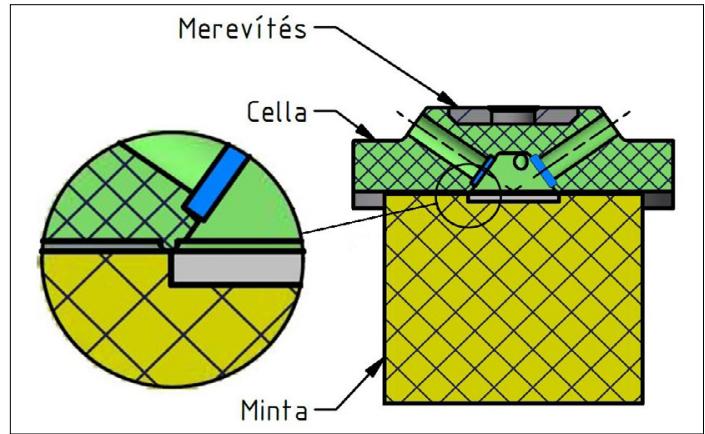

3. ábra. A minta és a cella közötti tömítőajak

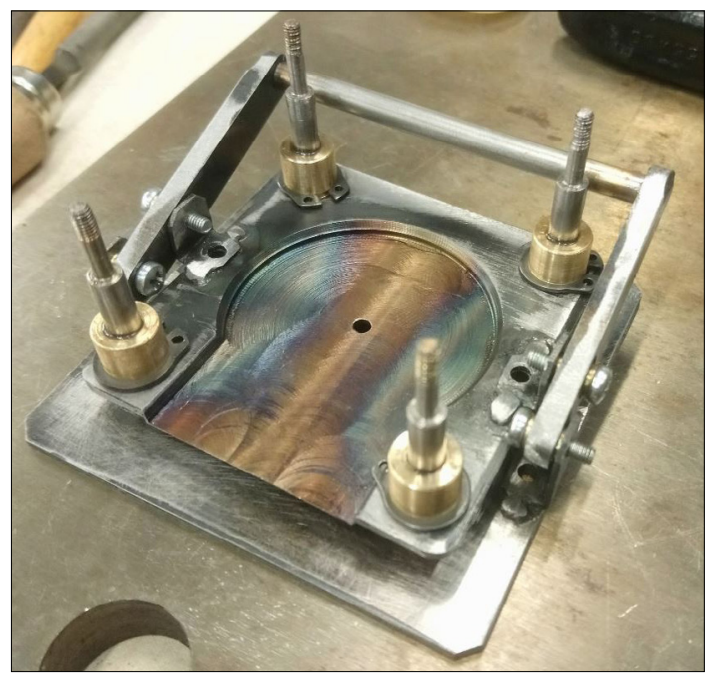

4. ábra. A mintatartó tálca és az emelömechanizmus a vázszerkezetre építve

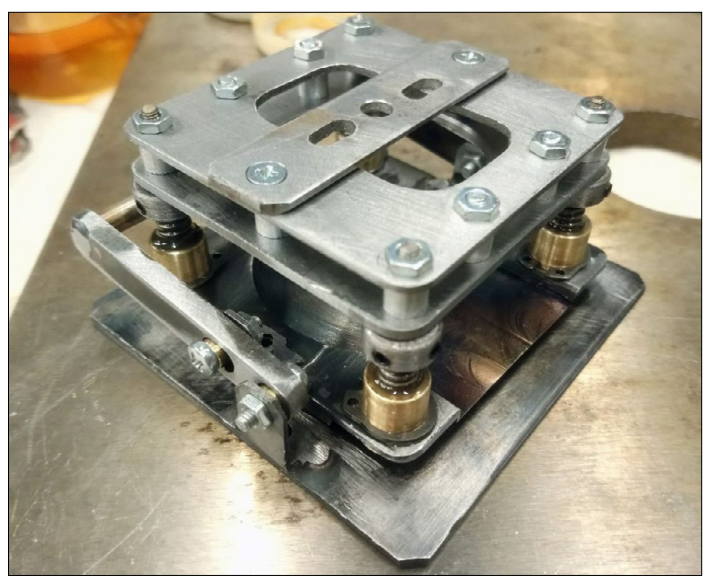

5. ábra. Az összeszerelt készülék cella nélkül

biakban lehetőség nyílik az eszköz gyakorlatban történő alkalmazására, a színes maratás és az ellipszometriai vizsgálat kombinálásával. 


\section{Következtetések}

A mikrofluidikai cellákkal kapcsolatos eddigi ismereteket felhasználva újragondoltuk a különböző maratási folyamatok vizsgálatához kialakított konstrukciót. $\mathrm{E}$ tapasztalatok függvényében egy új készüléket terveztünk, amely egyaránt képes optikai mikroszkóppal és spektroszkópiai ellipszométerrel is vizsgálatokat folytatni. A kialakított vázszerkezet könnyen szerelhető, így alkalmas lehet új, módosított cellák behelyezésére is. A konstrukció későbbi, ismételt továbbfejlesztésével egy olyan eszközhöz juthat a metallográfia, amely új fejezetet nyithat a maratási folyamatok in situ vizsgálatában.

\section{Köszönetnyilvánítás}

A publikáció az Emberi Erőforrások Minisztériuma NTP-SZKOLL-20-0067 kódszámú Nemzeti Tehetség Program pályázatának támogatásával valósult meg.

\section{Szakirodalmi hivatkozások}

[1] Renkó J. B., Bonyár A., Szabó P. J.: Mikrofluidika cella fejlesztése folyadékfázisú vékonyréteg leválasztás nyomonkövetésére. Acta Materialia Transylvanica, 3/2. (2020) 94-98. https://doi.org/10.33924/amt-2020-02-08

[2] A. Bonyár, P. J. Szabó: Correlation between the grain orientation dependence of color etching and chemical etching. Microscopy and Microanalysis, 18/6. (2012) 1389-1392.

https://doi.org/10.1017/S1431927612013554

[3] Bonyár A., Renkó J., Kovács D., Szabó P. J.: Understanding the mechanism of Beraha-I type color etching: Determination of the orientation dependent etch rate, layer refractive index and a method for quantifying the angle between surface normal and the $\langle 100\rangle$, $\langle 111\rangle$ directions for individual grains. Materials Characterization, 156. (2019) 109844.

https://doi.org/10.1016/j.matchar.2019.109844

[4] Tompkins H. G.: A User's guide to Ellipsometry. Academic Press, Inc., Mesa, Arizona, 1993. XIII-XV.

[5] Bonyár A., Sántha H., Ring B., Varga M., Kovács J. G., Harsányi G.: 3D Rapid Prototyping Technology (RPT) as a powerful tool in microfluidic development. Procedia Engineering, 5. (2010) 291-294. https://doi.org/10.1016/j.proeng.2010.09.105

[6] H. D. Cho, Y. T. Jun, M. Y. Yang: Five-axis CNC milling for effective machining of sculptured surfaces. International Journal of Production Research, 31/11. (1993) 2559-2573. https://doi.org/10.1080/00207549308956883

[7] Tompkins H. G. , Hilfiker J. N.: Spectroscopic ellipsometry: Practical application to thin film characterization. Momentum Press, LLC, New York, 2016. 31-55.

[8] Fujiwara H.: Spectroscopic Ellipsometry: Principles and Applications. John Wiley \& Sons Ltd, Chichester, 2007. 81-120. 